\title{
Recent Foraminifera from the Chilka Lake, Orissa, East Coast of India
}

\author{
Anil kumar .R ${ }^{1}$, Gangadhara Rao .K ${ }^{2}$ \\ Andhra University, Department of Geology, Vishakhapatnam, Andhra Pradesh, India
}

\begin{abstract}
Chilka Lake is a brackish marine lagoon in the Orissa State, India. The Lake is divided into the Outer Channel, the Northern Sector, the Central Sector and the Southern Sector for the present study. A total of eighty eight species of foraminifera have been identified from the Chilka Lake. Asterorotalia inflata, A. Trispinosa, Cibicides lobatulus, Nonion grateloupi, Pararotalia nipponica, Ammobaculites exiguous, Miliammina fusca, M. fusca var., Quinqueloculina seminulum, Ammonia beccarii, A. Tepida, Elphidium craticulatum and Nonion deprssulus are abundant occurecne. Although the endemic species tolerate wide fluctuations in ecological variables, their reproduction is active under conditions of salinity from $30.0 \%$ to $40.0 \%$ and temperature from $27^{0}$ to $32^{\circ}$ C. Faunal sequences obtains from Outer Channel to the inner lake and from Northern Sector through Central Sector to Southern Sector, Miliammina fusca dominating in the Outer Channel and Quinqueloculina seminulum, the Central and Southern Sectors.
\end{abstract}

Keywords: Foraminifera, Endemic, Stenohaline, Chilka Lake, Biofacies

\section{Introduction}

When you submit your paper print it in two-column format, including figures and tables [1]. Chilka Lake is a brackish water lagoon, spread over the Puri, Khurda and Ganjam district of Odisha state on the east coast of India. It is the largest lagoon $\left(1165 \mathrm{~km}^{2}\right)$ in India and second largest in the world and is located between $19^{\circ} 25^{1}$ and $19^{\circ} 54^{1} \mathrm{~N}$ and $85^{\circ} 6^{1}$ and $85^{\circ} 38^{1} \mathrm{E}$. It can be three major environments: (i) estuarine (ii) lagoonal and (iii) lacustrine (Fig. 1). Estuarine characters: as the from various rivers are drained into the bay of Bengal flowing through this lake, it has the estuarine characters towards the sea where the waters are influenced by the saline water of the sea, salinity being extended toward the other sides of the lake where the fresh waters are drained into the lake by a number of rivers and streams. Lagoonal characters : the lake is separated from the sea by a 183 to $274 \mathrm{~m}$ wide spit and sea water enters into the lake through various channels, especially at the time of high tide. Hence, it has the characters of a lagoon. Lacustrine characters: chilka lake is land locked on three sides and is separated from the sea by a sand spit and receives water from the land by various rivers and streams from the catchment area. It being a large lake receives water, whenever there are rains. Geology: geological studies indicate that the coast line extended along the western shores of the lake in the Pleistocene era with its northern region lying under the sea. That the coast line has moved eastward over the ages is supported by the fact that the nearby konark sun temple, built originally on the seashore a few hundred years ago, is now about $3 \mathrm{~km}$ away from the coast. The catchment area of Chilka Lake has a rock, sand and mud strata. It contains a wide range of sedimentary particles such as clay, silt, sand, gravel and shell banks but the majority area of the catchment area is characterized by containing silt. The Daya and Bhargavi rivers and other streams deposit about 1.6 million metric tons of silt into the Chilka Lake (Iwasaki, Shimpei, 1998). Geography and topography: Chilka Lake is a shallow bar-built estuary with large areas of mudflats. The western margin and southern margins of the lake are fringed by the Eastern Ghat hill range (Tripathy, Balaram, 2007-2011). Several inland rivers, which brings silt into the lake, control the northern end of the lake. A $60 \mathrm{~km}$ long barrier beach called Rejhansa (Singh et al. 2005) formed by northerly currents in the Bay of Bengal, resulted in the formation of this shallow lake and forms its eastern side. Hydrology: the hydrological subsystems control the hydrology of the lake. The land based system comprises distributaries of the Mahanadi River on the northern side, 52 river channels from the western side and the bay of Bengal on the eastern side. Two of the three southern branches of the Mahanadi river that trifurcates at Cuttack, feed the lake. All the inland river systems discharge an annual flow of about 0.375 million cubic meters of fresh water which is estimated to carry 13 million metric tons of silt into the lake. On the northeast a channel connects the lake to the Bay of Bengal. Water quality: the lake water is alkaline $\mathrm{P}^{\mathrm{H}}$ ranging from 7.1 to 9.6. The southern sector of the lake has highest alkalinity. Salinity levels in the lake show wide temporal and spatial variation due to complex blend fresh water discharge, evaporation and tidal inflow of seawater.

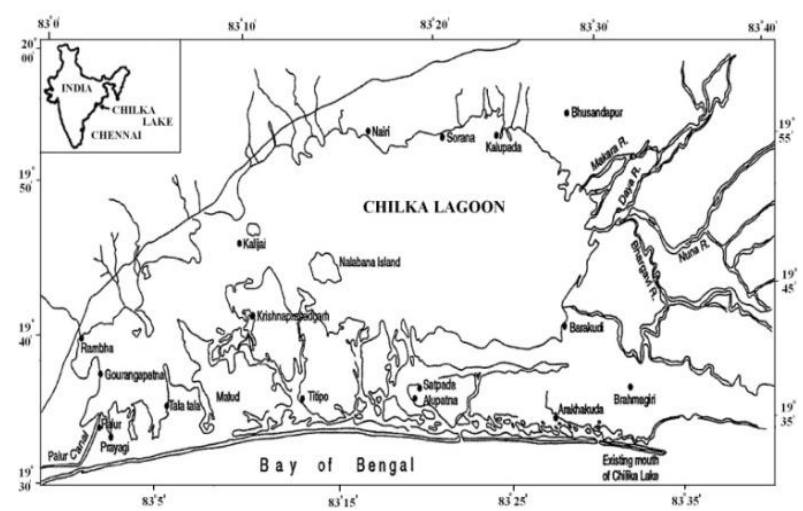

Figure 1: General location map of Chilka Lake

\section{Materials and Methods}

Sediment samples for foraminiferal studies, sediment texture analysis and determination of organic matter content and water samples for the determination of salinity and dissolved

\section{Volume 4 Issue 11, November 2015}




\section{International Journal of Science and Research (IJSR) \\ ISSN (Online): 2319-7064}

Index Copernicus Value (2013): 6.14 | Impact Factor (2014): 5.611

oxygen content were collected from 50 stations (Fig. 2) during May and December (pre-monsoon and post-monsoon seasons) from the lake. Temperature and hydrogen-ion concentration were measured at all the 50 stations. The sediment sample preserved in neutralised formaldehyde was washed free of silt and clay over an ASTM-230 mesh sieve having openings of $0.063 \mathrm{~mm}$. the sieve with the residue was kept immersed in an aqueous solution of rose Bengal (which has prepared by dissolving $1 \mathrm{gm}$ of rose Bengal dye in one litre of water) for an hour. Then the material on the sieve was gently washed to free it of the excess stain and dried. The foraminifera tests were separated from the residue that is mostly of terrigenous sand by floatation in carbon tetrachloride. The residue was examined and if foraminifera tests were left in the residue they were picked and added to the floated crop. The foraminiferal crop was examined under a binocular microscope.

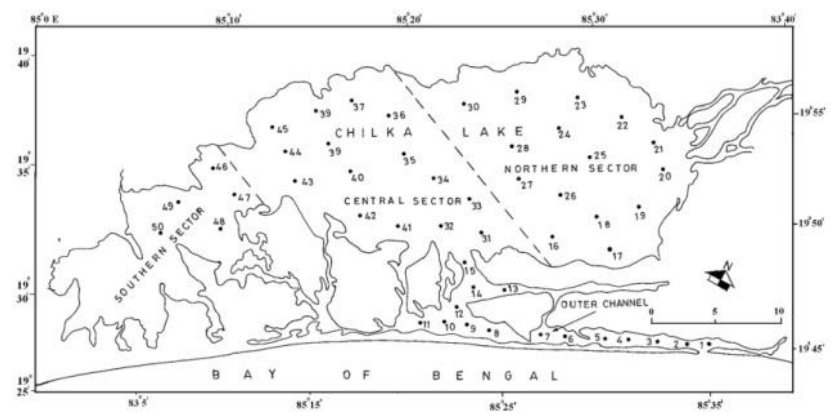

Figure 2: Sampling locations of study area

\section{Results and Discussions}

The Chilka Lake constitutes an estuarine, lacustrine and lagoonal environments. Morphologically and ecologically the lake is divisible into four segments: (i) the outer channel (ii) the northern sector (iii) the central sector and (iv) southern sector. The total foraminifera population varies from station to station in the lake. In contrast, the size is not only larger but increases upstream from the mouth. The bigger population size in December may be result of (i) higher salinity which cause mortality (ii) the decreased downstream flow velocity. Eighty eight foraminiferal species of the chilka lake are sorted into six groups. Abundant Rotalids (Ammonia beccarii and A. Tepida), abundant Miliolids (quinqueloculina seminulum), abundant Nonionids (Nonion depressulus), abundant Textularids (Ammobaculites exiguous, Miliammina fusca, and Miliammina fusca var. And all other agglultinated forms of common to scarce occurence). Stenohaline marine forms are Asterorotalia inflata, A. Trispinosa, Cibicides lobatulus, Pararotalia nipponica and Nonion grateloupi.

\section{Conclusions}

The Chilka Lake is a brackish water lagoon. Based on the physical and chemical parameters, the lake is divided into Southern, Central and Northern Sectors and the Outer Channel. Sediment and water samples were collected from 50 stations in the Chilka Lake for foraminiferal studies. Ammonia beccarii, Quinqueloculina seminulum, Ammonia tepida, Elphidium craticulatum, Elphidium simplex, Nonion depressulus, Quinqueloculina lata, and Quinqueloculina subcuneata are both abundant and wide spread in the lake. Ammonia beccarii is the most euryhaline eurythermal species due to that it reproduces high percentage. Elphidium craticulatum, Nonion depressulus and Quinqueloculina lata are stenohaline estuarine forms. Ammonia tepida is moderately euryhaline and has greater reproduction rate in the observation period. The foraminifera fauna of the lake is dominated by Ammonia beccarii, Quinqueloculina seminulum and Elphidium simplex constitute the important accessories.

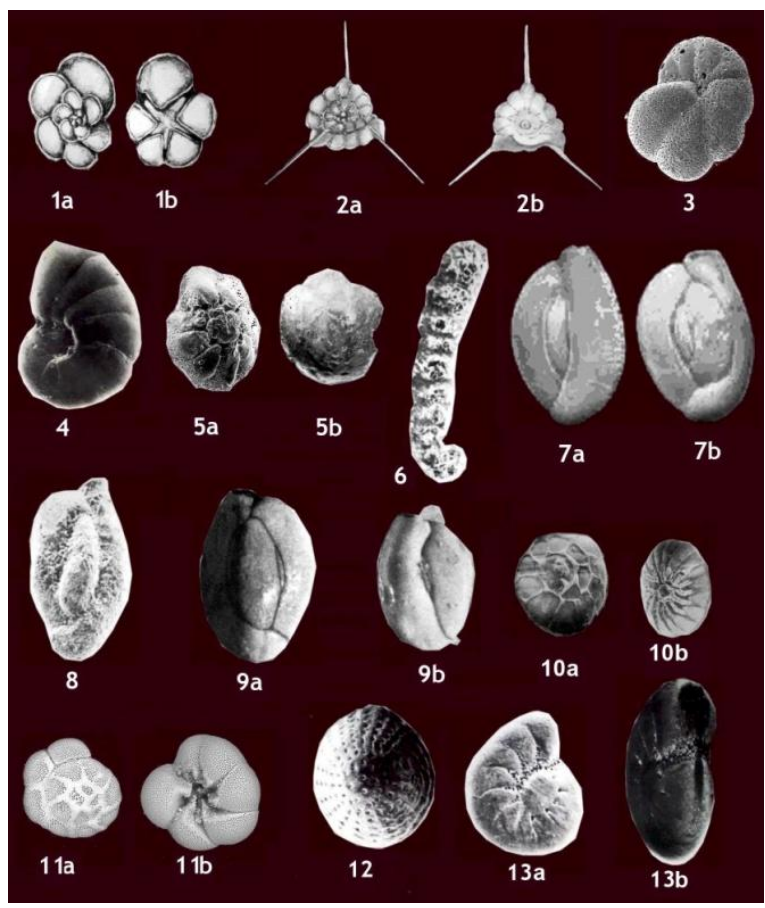

1. Asterorotalia inflata (a) Spiral side view (b) Umbilical side view 2. A. trispinosa, (a) Dorsal view, (b) Ventral view 3. Cibicides lobatulus (General view) 4. Nonion grateloupi (General view) 5. Pararotalia nipponica (a) Umbilical side view (b) Spiral side view 6. Ammobaculites exiguus (General view) 7. Miliammina fusca (a) Four chamber side view (b) Three chamber side view 8. M. fusca var. (General view) 9. Quinqueloculina seminulum (a) Four chamber side view (b) Three chamber side view 10. Ammonia beccarii (a) Spiral side view (b) Umbilical side view 11. A. tepida (a) Oblique spiral side view 12. Elphidium craticulatum (General view) 13. Nonion depressulus (a) General view (b) Apertural view

\section{References}

[1] Boltovskoy, E. and Wright, R. Recent foraminifera, Dr. W. Junk K B V, Publishers, The Hague, 1976.

[2] Carver, R. E. (Editor). (1971). Sedimentary petrology. John Wiley and sons, Inc., London, 653p.

[3] Chilka Lake Dovelopment Authority, Orissa, 2008 History of chilka Lake"

[4] Chilka Lake Dovelopment Authority 2008. About Chilka lagoonhttp://www.chilka.com/about.him

[5] Folk, R. L. (1954). The distinction between grain size and mineral composition in sedimentary rock nomenclature. Jour. Geol., Vol. 62, pp. 344-359. 
[6] Iswaki, Shimpei(1998). Sustainable Regional Dovelopment in the catchment of chilka Lagoon Orissa State, Proceedings of the International workshop in sustainable Development of chilka Lake Tokyo Japan, G lobel. Environment Information Centre,pp.27

[7] Loeblich, A. R. Jr, and H. Tappan (1988). Foraminiferal genera and their classification. Van Nostrand Reinhold Company, New York.

[8] Singh, Sarina, Bindloss, Joe, Clammer, Paul and Eberle, Janine (2005). Lonely Planet, India, a travel guide, 576p.

[9] Strickland, J. D. H. and Parsons, T. R. (1968). A practical hand book of sea water analysis. Bull. Fisheries Res. Board of Canada, No. 167, 311p.

[10] Sverdrup, H. U., Johnson, M. W. and Fleming, R. H. (1942). "The Oceans Prentice-Hall, New York", 1087 p.

[11] Tripathy, Balaram (2007-11). Maritime Heritage of Orissa.Orissa Review. Govt. of Orissa. pp.7-41 and pp.27-41. 